\title{
Trade Led Growth in China since 1978: An Empirical Investigation
}

\author{
Preeti Sharma $^{1}$ and Priyanka Sahni ${ }^{2}$ \\ ${ }^{1 \& 2}$ Assistant Professor, Department of Economics \\ ${ }^{1}$ SNRL Jairam Girls College, Kurukshetra, Haryana, India, ${ }^{2}$ Hindu Kanya Mahavidayalya, Jind, Haryana, India \\ E-Mail: preetisharma2388@gmail.com, priyanka.sahni52@gmail.com
}

\begin{abstract}
The aim of this study is to explore the causal relationship between the exports, imports and economic growth of Chinese economy using time series data running from 1978 to 2016. Co integration, Granger Causality analysis and Vector Error Correction Mechanism (VECM) has been used in order to test the hypotheses about the presence of causality and co integration among the variables. The co integration test confirmed that exports, imports and GDP are co integrated, indicating an existence of long run equilibrium relationship among the variables and also confirmed by the Johansen co integration test results. The Granger causality test finally confirmed the presence of bi-directional causality between exports, imports and GDP. The study further shows that relative share of china's exports in world exports has increased significantly after the introduction of economic reforms. Further, the rising exports have also made a significant contribution to the economic growth of Chinese economy due to forward and backward linkages.

Keywords - Foreign Trade, Economic Growth, Exports, Co integration, Granger Causality
\end{abstract}

\section{INTRODUCTION}

International trade assumes to be having great significance in the economic development of both developed and developing countries. And as the process of globalization of economies gathers momentum foreign trade becomes one of the major important components of economic growth. International trade not only involves the flow of goods and services across the countries, but also the factors of production, labor and capital. It facilitates an efficient allocation of resources across countries generally leading to greater specialization of output as well as accelerated economic growth. It offers countries a potentially powerful mechanism to achieve a higher, stable and steadily increasing standard of living than would otherwise be feasible, allowing them to exploit opportunities beyond their own geographical boundaries. Traditionally of course, international trade has always been given a pride of place in the economic progress of nations. John Stewart Mill, for example, had argued long ago that "International trade acts as a source of industrial revolution in a country whose resources are underdeveloped." According to Alfred Marshall the causes which determine the economic progress of nations belong to the realm of international trade. The growth effects of trade openness are made more explicit by the use of the new growth theory led by Romer (1986) and Lucas (1988). Within such framework, Grossman and Helpman (1991) establish that trade openness enhances economic growth through following channels.
1. Trade enlarges the available variety of intermediate goods and capital equipment, which can expand the productivity of the country's other resources.

2. Trade permits developing countries the access to improved technology in developed countries, in the form of embodied capital goods.

3. Trade allows intensification of capacity utilization that increases products produced and consumed.

4. Openness offers a larger market for domestic producers, allowing them, on one hand, to operate at minimum required scale, and on the other hand, to reap benefits from increasing returns to scale.

In this era of open economy, nations are concerned with increasing the quality of life of their citizens. And, the quality of life mainly comes from the macro-economic prosperity. Thus, increasing Gross domestic Product is the most important objective of any economy. There are different approaches to achieve this target. One possibility is to find new export market for goods and services, as exports, along with the imports of new technologies, is an important engine for development. This strategy, however, raises the question: Should a country promote exports or imports to speed up economic development and growth, or should it primarily focus on economic growth to generate international trade? In the literature there has been considerable debate on Export driven growth and Growth driven exports hypothesis, with special reference to their implications on development policies and international trade. It is widely believed that exports are crucial in providing the impetus for economic growth in developing countries. Thus, export-led growth has been put forward as an efficient alternative to inward oriented strategy of development.

Exports provide foreign exchange that allows for increasing levels of imports of capital goods and intermediate goods that in turn raise the growth of capital formation and thus stimulate output growth. Furthermore, export growth may promote the diffusion of technical knowledge (Grossman and Help-man, 1991) and enhance efficiency through the international competition (Kruger, 1980). Rivera- Batiz (1985) argues that a rise in economic activity would induce an increase in imports, the reason being that high real income promotes consumption. In that regard, there is a direct connection between economic growth and imports. Recent endogenous growth models have emphasized the importance of imports as an important channel for foreign technology and knowledge to flow into the domestic 
economy (Lee, 1995). New technologies could be embodied in imports of intermediate goods such as machines and equipments and labor productivity could increase over time as workers acquire the knowledge to 'unbundle' the new embodied technology (Thangavelu and Rajaguru, 2004). Moreover, it is widely acknowledged that imports play a central role in the countries whose manufacturing base is built on export oriented industries (Esfahani, 1991).

The Present Paper has been divided into five sections. Section- I is devoted to Review of Literature. Section -II analyzes the trends in Chinese economy since 1980s. In Section-III we have discussed about the methodology and data sources. Section - IV deals with the empirical results and their interpretation. The main conclusions emerging out of the study are discussed in the Section- $\mathrm{V}$.

\section{REVIEW OF LITERATURE}

Traditional economic theory establishes trade as an engine of economic growth. Since the beginning of early 1980s economists have supported and recommended market oriented reforms that included as a fundamental component the reduction of trade-barriers and the opening of International trade to foreign competition (Edwards, 1993). Many empirical studies have been undertaken to establish the relation between exports, imports and economic growth. The prominent among them are:

Balaguer (2002) examined the hypothesis of export-led growth from the Spanish trade liberalization process initiated four decades ago, for 1961 to 2000. Both the export expansion and the progression from "traditional" exports to manufactured and semi-manufactured export is considered for this purpose. It is proved that the structural transformation in export composition has become a key factor for Spain's economic development along with the relationship between export and real output.

Mallick (1996) investigated empirical evidence with reference to India to establish the causation between exports and economic growth over the period 1950-51 to 1991-92, using co-integration based on Error Correction Model (ECM). The study explains that the expansion of productive capacity through income growth can raise exports, and increased probability of exports can induce increased savings and thereby capital accumulation, which give rise to economic growth.

Lie et al., (1997) analyzed the casual relationship between trade openness and economic growth in China by using the quarterly data over the period from 1983, Quarter III to 1995 Quarter I. The empirical results showed that a feedback casual relationship exists between openness to trade and economic growth. The study further reveals that a higher degree of trade openness is related to higher economic growth in Chinese economy.

Olugbenga (1997) found significant variation in the real output levels due to the changes in exports, imports, gross investment and trade policy in 12 Sub-Saharan African countries for the period 1965-1991 using vector Autoregression technique augmented with error correction term. The study concludes that sizeable variations in real output growth in ten of the twelve countries are due to the changes in trade policies and exports, with some contributions from shocks to gross investment.

Shan and Sun (1998) examined the export-led growth hypothesis for China over the period from 1987 to 1996 using monthly data. The empirical estimation is based on augmented growth equation and Granger Causality test. The results clearly indicate the bi-directional granger causality between real exports and industrial output in China.

Bo Nai Fan et al., (2005) studied the relationship through Granger causality model and broad difference approach, using Chinese statistics from 1952 to 2003. The result showed that Chinese GDP and export had a clear one-way causal relationship. That is to say, the export was an important factor to promote Chinese economic growth.

Jordan (2007) analyzed the causality between exports and GDP of Namibia for the period 1970-2005. The results of the study revealed that exports Granger cause GDP and suggested that the export-led growth strategy through various incentives has a positive influence on economic growth.

Tang (2006) analyzed the relationship between exports, real GDP, and imports in china by using Granger Causality approach. He stated that there is no long run relationship among export, real Gross Domestic product and imports. This study further shows no long-run and short-run causality between export expansion and economic growth in China on the basis of Granger causality while economic growth does Granger-cause imports in the short run.

\section{TRENDS IN CHINESE ECONOMY SINCE 1978}

Prior to the initiation of economic reforms and trade liberalization 36 years ago, China maintained policies that kept the economy very poor, stagnant, centrally-controlled, vastly inefficient, and relatively isolated from the global economy. Since opening up to foreign trade and investment and implementing free market reforms in 1978, China has been among the world's fastest-growing economies, with real annual Gross Domestic Product (GDP) growth averaging nearly $10 \%$ through 2014 . In recent years, China has emerged as a major global economic power. It is now the world's largest economy (on a purchasing power parity basis), manufacturer, merchandise trader, and holder of foreign exchange reserves. The World Bank estimates that from 1981 to 2010, 679 million people in China were raised out of extreme poverty. China has emerged as a major global economic power. It is now the world's largest economy (on a purchasing power parity basis) manufacturer, merchandise exporter and importer, and holder of foreign exchange reserves. 
Beginning in 1978, China launched several economic reforms. The central government initiated price and ownership incentives for farmers, which enabled them to sell a portion of their crops on the free market. In addition, the government established four Special Economic Zones along the coast for the purpose of attracting foreign investment, boosting exports, and importing high technology products into China. Additional reforms, which followed in stages, sought to decentralize economic policymaking in several sectors, especially trade. Economic control of various enterprises was given to provincial and local governments, which were generally allowed to operate and compete on free market principles, rather than under the direction and guidance of state planning. In addition, citizens were encouraged to start their own businesses. Additional coastal regions and cities were designated as open cities and development zones, which allowed them to experiment with free market reforms and to offer tax and trade incentives to attract foreign investment. In addition, state price controls on a wide range of products were gradually eliminated. Trade liberalization was also a major key to China's economic success. Removing trade barriers encouraged greater competition and attracted FDI inflows. China's gradual implementation of economic reforms sought to identify which policies produced favorable economic outcomes (and which did not) so that they could be implemented in other parts of the country, a process Deng Xiaoping reportedly referred to as "crossing the river by touching the stones."

China has had a remarkable period of rapid growth shifting from a centrally planned to a market based economy. Today, China is an upper middle-income country. The post 1978 reforms marked the start of a gradual and highly coordinated transition process in China. The initial focus of reform was to promote exports by attracting FDI. In 1979, an export-processing law was passed that provided incentives for the processing and assembly of imported inputs. These incentives were expanded in 1987 to provide for the duty-free imports of all raw materials, parts and components used in export production. Monopoly state trading was liberalized starting in the late-1970s and replaced with a complex and highly restrictive set of tariffs, non-tariff barriers and licenses. Reform of the complex import control regime was more cautious during the early transition years, but was strengthened from 1992 onward by extensive reforms that China agreed to implement as part of the WTO accession process. Accordingly, a dualistic trade regime existed from the mid-1980s onward, one that promoted exports via FDI alongside controlled liberalization of a protected domestic sector (Wignaraja, 2011).

An important ingredient in China's economic reforms since 1978 has been the economic policy termed open-door. The objective of this policy, which ended 36 years of economic semi-isolation from the rest of the world, was to expedite China's industrialization and modernization through economic interaction and integration with the world economy. In its transition from a centrally-planned to a market economy, China diverged from the "shock" approach to economic reform used in the Soviet Union. Instead, China followed the successful East Asian economies in combining export-oriented opening up to the global economy with maintaining a leading role for the government in allocating and mobilizing resources towards selected industrial sectors and investment, including infrastructure.

The government also encouraged and subsidized savings, especially by companies; forfeited dividend from SOEs, channeled cheap credit to industry; underpriced key industrial inputs - energy, resources, land, and the environment; and managed the exchange rate. In this policy setting, investment reached a very high share of GDP while industry rather than services drove much of the growth. With the link between production and consumption loosened by access to the open multilateral trading system, China became an export powerhouse. Industrial companies became increasingly profitable under this pattern of growth, which also benefited parts of the government, directly or indirectly. Thus, a constituency was built up in favor of maintaining the pattern of growth.

China's growth model has been very good for the supply side. Looking at the drivers of "potential" GDP (production) growth, reflecting China's towering investment to GDP ratio, the contribution of capital accumulation has been very high. An important driver, particularly since the late 1990s, is that in a policy setting favorable to industry and capital, flourishing industrial firms ploughed back increasingly large profits into new capacity. With wage increases lagging behind productivity growth, the share of companies' profits in GDP could rise - pushing up the national savings rate.

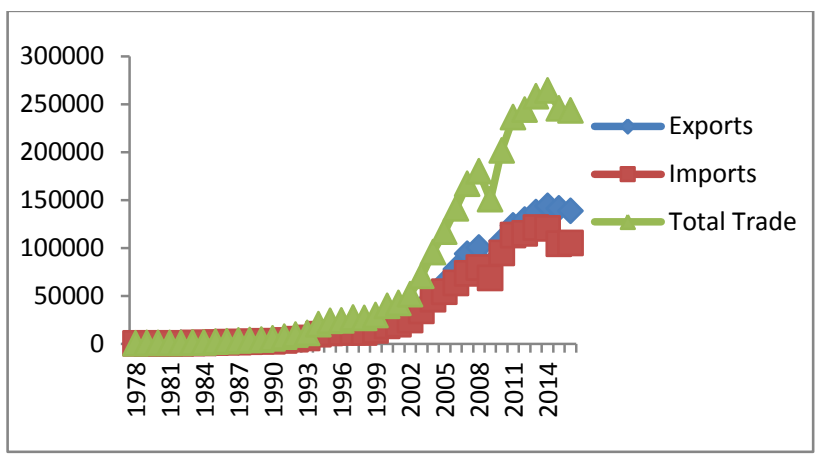

Fig. 1 China's Trade Volumes: 1978-2016

Fig. 1 shows that China's Trade has increased during the period under study i.e. 1978-2016. It may be due to the aggressive trade liberalization and various export promotion schemes adopted by the government of Chinese economy. Rapid export growth has been largely driven by china's participation in vertically integrated global production supply chains - where different activities in the production of single good are carried out in different economies. 


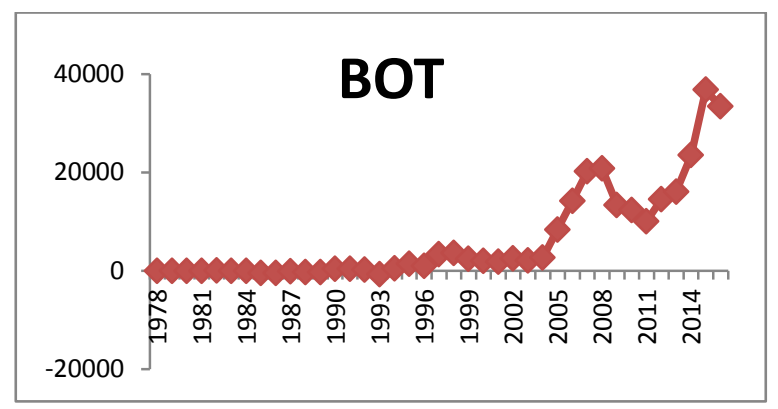

Fig. 2 China’s Trade Balance: 1978-2016

Fig. 2 shows that China experienced trade deficit for the period 1978 to 1981 . The trade surplus ratio was found to be positive during the period 1982 and 1983. But it was found to be negative from 1984 to 1989 which implies that Chinese economy was experiencing the trade deficit due to large volume of imports. It showed rising trend from 1994 to 2000. But After the entry of China in WTO in 2001 it maintains an economically significant trade surplus till 2011. The ratio declined in the year 2012 but again shown an increasing trend from 2013 to 2016 . The Ratio was found to be highest in the year 2015 .

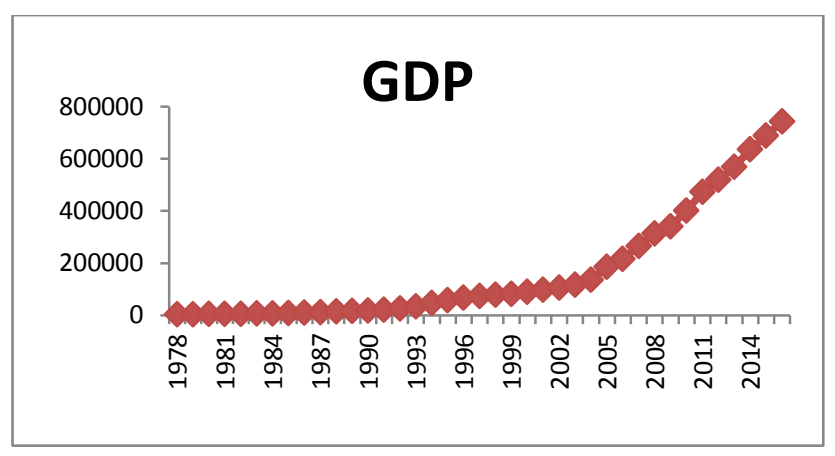

Fig. 3 Gross Domestic Product of China: 1978-2016

Fig. 3 reveals that GDP of China has followed a continuous upward trend for the period 1978-2014. This spectacular growth of China's GDP since 1978 indicates China's success. This is because; China has encouraged Foreign Direct Investment (FDI) by multi-nationals looking to set up export - oriented manufacturing operations. China launched its economic transformation by using abundant labor at low wage rate to establish manufacturing for export industries. Chinese Special Economic Zones (SEZs) and Export Processing Zones (EPZs) promoted Chinese exports as well as attracted FDI because of which the percentage share of china's exports in GDP has also shown an impressive performance during the period under study. The overall contribution of exports to GDP is higher as shown in fig. 1.4 because of forward and backward linkages. In this way, China's export sector has proved pivotal to Chinese economic growth and industrialization over recent decades. Its development has led to the dissemination of new technologies and business practices to the wider economy, driving productivity gains and wage growth, and has supported the ongoing transition of China's productive capabilities higher up the value chain.

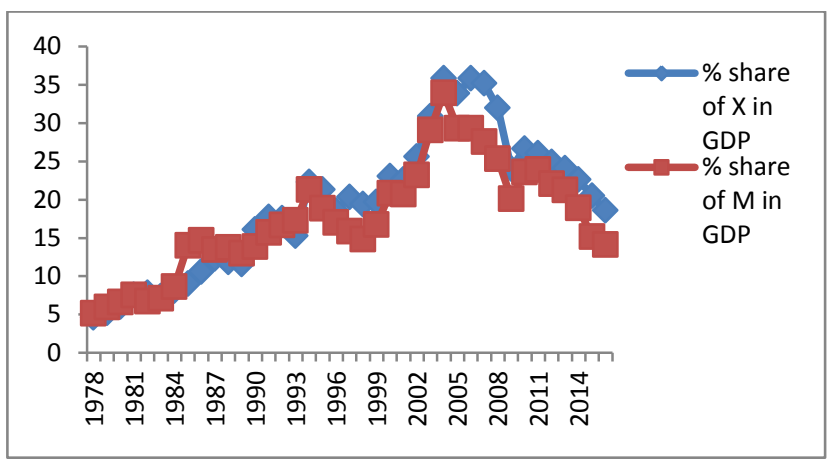

Fig. 4 Percentage Share of China's Exports \& Imports in Gdp : 1978-2016

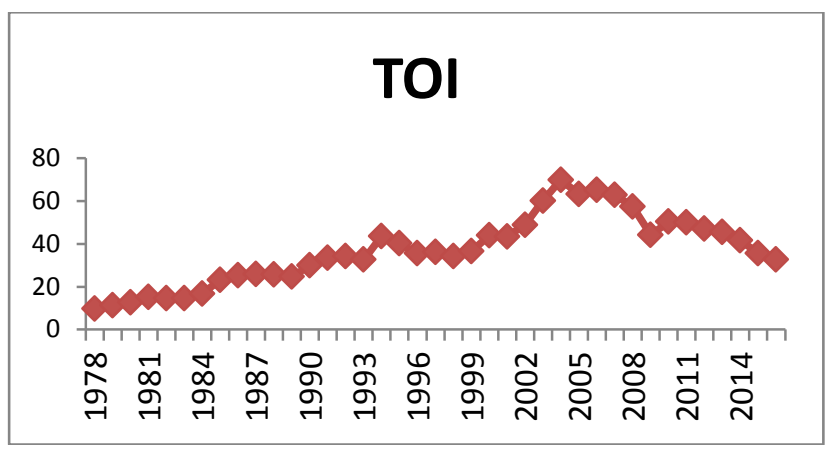

Fig. 5 Trade Openness Index of China: 1978-2016

\section{DATA AND METHODOLOGY}

The data used for this study are basically time series data for China covering the period 1978- 2016. The three economic variables included in this study are the Exports, Imports and Gross Domestic Product (GDP). Gross Domestic Product at Market Prices (GDP) is an indicator to measure economic growth. Data were sourced from Statistical Yearbook of China (various issues).

\section{HYPOTHESIS OF THE STUDY}

The present paper is based on the following hypotheses for testing the causality and co integration between exports, imports and economic growth (GDP) in India Export and/or import and GDP are co integrated? Export and/or import Granger causes GDP or vice versa?

\section{METHODOLOGY}

In order to avoid spurious regression, we need to distinguish the stationary of the series. By doing so, we ensure the validity of the usual test statistics (t-statistics, F-statistics and R2). Stationary could be achieved by appropriate differencing and this appropriate number of differencing is called order of integration. The standard Augmented Dickey Fuller (ADF) [Dickey and Fuller 1979] Unit root tests and Correlogram test have been used to check the stationary of the series. Once the unit roots are confirmed for data series, the next step is to examine whether there exists a long-run equilibrium relationship among the variables. This calls for co integration analysis which is significant so as to avoid the risk of spurious regression. Co integration analysis is 
important because if two non-stationary variables are co integrated, a VAR model in the first difference is misspecified due to the effect of a common tend. In this stage, the Johansen (1988) co integration test is used to identify a co integrating relationship among the variables. In our present research study, we have used Johansen test to assess the co integration of the interest variables. We have applied two maximum likelihood tests, the Trace test and Maximum Eigen value tests, advocated by Johansen (1988) and Johansen and Juselius (1990). If a co integration relationship is identified, the model should include residuals from the vectors (lagged one period) in the dynamic Vector Error Correcting Mechanism (VECM) system.

A Vector Error Correction Model (VECM) is a restricted VAR designed for use with non-stationary series that are known to be co integrated. Once the equilibrium conditions are imposed, the VECM describes how the examined model is adjusting in each time period towards its long-run equilibrium state. Since the variables are supposed to be co integrated, then in the short-run, deviations from this longrun equilibrium will feedback on the changes in the dependent variables in order to force their movements towards the long-run equilibrium state. Hence, the cointegrated vectors from which the error correction terms are derived are each indicating an independent direction where a stable meaningful long-run equilibrium state exists. The VECM has co integration relations built into the specification so that it restricts the long-run behavior of the endogenous variables to converge on their co integrating relationship while allowing for short-run adjustment dynamics. The co integration term is known as the error correction term since the deviation from long-run equilibrium is corrected gradually through a series of partial short-run adjustments. The dynamic specification of the
VECM allows the deletion of the insignificant variables, while the error correction term is retained. The size of the error correction term indicates the speed of adjustment of any disequilibrium towards a long-run equilibrium state. The error correction term represents the long-run relationship. A negative and significant coefficient of the error correction term indicates the presence of long-run causal relationship. Granger causality test as proposed by Granger (1969) has also been used in order to determine the direction of causal relationship among variables.

\section{EMPIRICAL RESULTS AND DISCUSSION}

The present research study tries to empirically examine the causal relation between exports, imports and economic growth of Chinese economy for the period 1978-2016. Given the nature of problem and quantum of data we first study the data properties from an econometric perspective starting with the stationary of data. We employ co integration technique to investigate the causality between Indian exports, imports and economic growth. If the two variables are found to be integrated of same order, only then we can apply the co integration analysis. There are three steps involved in VECM analysis

1. Lag selection

2. Johansen Test of Co-integration

3. VECM

VAR Lag Order Selection Criteria

Endogenous variables: GDP EXPORTS IMPORTS

Exogenous variables: $\mathrm{C}$

Date: 06/14/18 Time: 13:05

Sample: 19782016

Included observations: 35

TABLE I VAR LAG LENGTH CRITERION

\begin{tabular}{|c|c|c|c|c|c|c|}
\hline Lag & LogL & LR & FPE & AIC & SC & HQ \\
\hline 0 & -1196.477 & NA & $1.17 \mathrm{e}+26$ & 68.54152 & 68.67484 & 68.58754 \\
\hline 1 & -1034.844 & 286.3210 & $1.92 \mathrm{e}+22$ & 59.81965 & 60.35291 & 60.00373 \\
\hline 2 & -1020.406 & 23.10117 & $1.43 \mathrm{e}+22$ & 59.50889 & 60.44210 & 59.83103 \\
\hline 3 & -1005.830 & 20.82202 & $1.07 \mathrm{e}+22$ & 59.19029 & 60.52345 & 59.65050 \\
\hline 4 & -979.0051 & $33.72289 *$ & $4.12 \mathrm{e}+21 *$ & $58.17172 *$ & $59.90482 *$ & $58.76999 *$ \\
\hline
\end{tabular}

* indicates lag order selected by the criterion

LR: sequential modified LR test statistic (each test at 5\% level)

FPE: Final prediction error

AIC: Akaike information criterion

SC: Schwarz information criterion

HQ: Hannan-Quinn information criterion

The lag order selection criterion shows that three lags should be chosen as lower the value, better the model .All the five criterions recommended to take 3 lags. Therefore we have taken three lags in our model meaning that optimum lag is 3 . Now, second step is Johansen test of cointegration. The pre-condition is that variables must be non- stationary at level but when we convert all the variables into first difference they become stationary i.e. integrated of same order.

$\mathrm{HO}$ : Variable is stationary

$\mathrm{H} 1$ : Variable is not stationary.

The table II shows that series belonging to exports, imports and GDP is not stationary at level value. It becomes stationary only when first difference is taken. The table further reveals that as the calculated ADF statistics exceed the tabulated critical values at $5 \%$ and $10 \%$ level of significance, therefore we reject the null hypothesis of unit root and non-stationary and conclude that variables are 
stationary only at the first difference. Strong evidence emerges that all the time series are I (I) at the 5\% and $10 \%$ Level of significance.

TABle Ii Augumented Dicky Fuller Test

\begin{tabular}{|c|c|c|}
\hline Variables & With Constant & $\begin{array}{c}\text { With Constant } \\
\text { \& Trend } \\
\end{array}$ \\
\hline Exports & $-4.715711 * *$ & $-5.221147 * *$ \\
\hline \multicolumn{3}{|c|}{ Critical Values } \\
\hline $5 \%$ level & -2.943427 & -3.536601 \\
\hline $10 \%$ level & -2.610263 & -3.200320 \\
\hline Imports & $-4.715566 * *$ & $-3.767616 * *$ \\
\hline \multicolumn{3}{|c|}{ Critical Values } \\
\hline $5 \%$ level & -2.943427 & -3.574244 \\
\hline $10 \%$ level & -2.610263 & -3.221728 \\
\hline $\begin{array}{l}\text { Economic } \\
\text { Growth (GDP) }\end{array}$ & $3.674646 * *$ & $4.460524 * *$ \\
\hline \multicolumn{3}{|c|}{ Critical Values } \\
\hline $5 \%$ level & -2.971853 & -3.580623 \\
\hline $10 \%$ level & -2.625121 & -3.225334 \\
\hline
\end{tabular}

$* \& * *$ denotes significance at $5 \%$ and $10 \%$ level of significance. The lag length was determined using Schwartz Information Criteria (SIC)

The table III shows that first hypothesis i.e. no co integration among variables can be rejected as p-value $(0.00 \%)$ is less than the critical value $(29.79 \%)$ at $5 \%$ level of significance on the basis of trace statistics. The second null hypothesis i.e. there is at most one co integrating equation, can also be rejected as p-value $(0.90 \%)$ is less than the critical vale $(15.49 \%)$ at $5 \%$ level of significance. The third statement i.e. there is at least two co integrating equation can't be rejected because p-value $(6.96 \%)$ is more than the critical vale $(3.84 \%)$ at $5 \%$ level of significance, rather we accept this null hypothesis i.e. there is at least two co integrating equations. This implies that our three variables exports, imports and GDP are co integrated i.e. all the variables have long run association among them. And the Maximum Eigen test statistics makes the confirmation of this result. After analyzing that there is significant co integration in the sample series we employ Granger causality test to know the causality between the two variables.

TABLE III JOHANSEN COINTEGRATION TEST RESULTS

\begin{tabular}{|l|l|l|c|c|c|}
\hline $\begin{array}{c}\text { Hypothesized } \\
\text { Number of } \\
\text { Co integrating } \\
\text { Equations }\end{array}$ & $\begin{array}{c}\text { Eigen } \\
\text { Value }\end{array}$ & $\begin{array}{c}\text { Trace } \\
\text { Statistics }\end{array}$ & $\begin{array}{c}\text { Critical Value } \\
\text { at 5\% } \\
\text { (p-value) }\end{array}$ & $\begin{array}{c}\text { Maximum } \\
\text { Eigen } \\
\text { statistics }\end{array}$ & $\begin{array}{c}\text { Critical Value } \\
\text { at 5\% } \\
\text { (p-value) }\end{array}$ \\
\hline None* & 0.794300 & 73.99150 & $29.79707(0.0000)$ & 53.76540 & $21.13162(0.0000)$ \\
\hline At Most $1 *$ & 0.392274 & 20.22610 & $15.49471(0.0090)$ & 16.93305 & $14.26460(0.0185)$ \\
\hline At Most 2 & 0.092312 & 3.293050 & $3.841466(0.0696)$ & 3.293050 & $3.841466(0.0696)$ \\
\hline
\end{tabular}

Granger causality is a statistical concept of causality that is based on prediction. The results of Pair-wise Granger causality test done for 4 Time lags between the two variables for which unit root test is carried out are shown in the following table IV.

Pairwise Granger Causality Tests

Sample: 19782016

Lags: 4

TABle Iv Granger Causality For The Period 1978 To 2014

\begin{tabular}{|l|c|c|}
\hline \multicolumn{1}{|c|}{ Null Hypothesis } & F-Statistic & Prob. \\
\hline $\begin{array}{l}\text { EXPORTS does not Granger } \\
\text { Cause GDP }\end{array}$ & $3.33647 *$ & 0.0248 \\
\hline $\begin{array}{l}\text { GDP does not Granger Cause } \\
\text { EXPORTS }\end{array}$ & 0.64866 & 0.6329 \\
\hline $\begin{array}{l}\text { IMPORTS does not Granger } \\
\text { Cause GDP }\end{array}$ & $3.98607 *$ & 0.0119 \\
\hline $\begin{array}{l}\text { GDP does not Granger Cause } \\
\text { IMPORTS }\end{array}$ & 0.78968 & 0.5425 \\
\hline $\begin{array}{l}\text { IMPORTS does not Granger } \\
\text { Cause EXPORTS }\end{array}$ & 1.89560 & 0.1413 \\
\hline $\begin{array}{l}\text { EXPORTS does not Granger } \\
\text { Cause IMPORTS }\end{array}$ & $3.20333 *$ & 0.0289 \\
\hline
\end{tabular}

The results of Granger Causality test shows that Exports does not Granger causes GDP can be rejected at the 5\% level of significance but it cannot be rejected that GDP does not Granger cause exports as the probability value is more than the calculated value of F-statistics. This implies that there is a one-way causality between GDP and exports. The results further shows that one way causality is also found to be present between GDP and imports and between imports and exports.

\section{A. Vector Error Correction Model}

The coefficients of Error Correction Term (ECM) contain information about whether the past values affect the current values of the variable under study. A significant coefficient implies that past equilibrium errors play a role in determining the current outcomes. The information obtained from the ECM is related to the speed of adjustment of the system towards long-run equilibrium. The short-run dynamics are captured through the individual coefficients of the difference terms. The results of VECM analysis are given in the following table $\mathrm{V}$. Dependent Variable: D(GDP)

Method: Least Squares 
Date: 06/14/18 Time: 13:11

Sample (adjusted): 19832016

Included observations: 34 after adjustments

$\mathrm{D}(\mathrm{GDP})=\mathrm{C}(1) * \mathrm{GDP}(-1)+12.6667661305 *$ IMPORTS $(-$ 1) - 633796.526927) + C(2)*(EXPORTS(-1) $1.69956786643 *$ IMPORTS(-1) + 19408.9537879) + $\mathrm{C}(3) * \mathrm{D}(\mathrm{GDP}(-1))+\mathrm{C}(4) * \mathrm{D}(\mathrm{GDP}(-2))+\mathrm{C}(5) * \mathrm{D}(\mathrm{GDP}(-3))$ $+\mathrm{C}(6) * \mathrm{D}(\mathrm{GDP}(-4))+\mathrm{C}(7) * \mathrm{D}($ EXPORTS(-1)) + $\mathrm{C}(8) * \mathrm{D}($ EXPORTS $(-2))+\mathrm{C}(9) * \mathrm{D}($ EXPORTS $(-3))+$ $\mathrm{C}(10) * \mathrm{D}($ EXPORTS $(-4))+\mathrm{C}(11) * \mathrm{D}($ IMPORTS $(-1))+$ $\mathrm{C}(12) * \mathrm{D}($ IMPORTS(-2)) $+\mathrm{C}(13) * \mathrm{D}($ IMPORTS(-3)) + $\mathrm{C}(14) * \mathrm{D}(\operatorname{IMPORTS}(-4))+\mathrm{C}(15)$

TABLE V Estimates For VeCM REgRESSION

\begin{tabular}{|l|c|c|c|c|}
\hline & Coefficient & Std. Error & t-Statistic & Prob. \\
\hline $\mathrm{C}(1)$ & -0.181533 & 0.050492 & -3.595301 & 0.0019 \\
\hline $\mathrm{C}(2)$ & -7.602798 & 1.614512 & -4.709037 & 0.0002 \\
\hline $\mathrm{C}(3)$ & 0.162300 & 0.208172 & 0.779645 & 0.4452 \\
\hline $\mathrm{C}(4)$ & 0.703241 & 0.177249 & 3.967524 & 0.0008 \\
\hline $\mathrm{C}(5)$ & 0.464510 & 0.193519 & 2.400329 & 0.0268 \\
\hline $\mathrm{C}(6)$ & -1.291199 & 0.170999 & -7.550907 & 0.0000 \\
\hline $\mathrm{C}(7)$ & 4.008220 & 1.192219 & 3.361982 & 0.0033 \\
\hline $\mathrm{C}(8)$ & 4.084322 & 1.298020 & 3.146579 & 0.0053 \\
\hline $\mathrm{C}(9)$ & 4.249406 & 0.781901 & 5.434714 & 0.0000 \\
\hline $\mathrm{C}(10)$ & 4.598207 & 0.989488 & 4.647056 & 0.0002 \\
\hline $\mathrm{C}(11)$ & -5.751796 & 1.543168 & -3.727265 & 0.0014 \\
\hline $\mathrm{C}(12)$ & -7.289252 & 1.860413 & -3.918082 & 0.0009 \\
\hline $\mathrm{C}(13)$ & -6.539330 & 1.233072 & -5.303282 & 0.0000 \\
\hline $\mathrm{C}(14)$ & -5.385579 & 1.346476 & -3.999759 & 0.0008 \\
\hline $\mathrm{C}(15)$ & 33553.07 & 5052.503 & 6.640880 & 0.0000 \\
\hline
\end{tabular}

R-squared 0.982223

Mean dependent var 21730.37

Adjusted R-squared 0.969124

S.D. dependent var 23199.43

S.E. of regression 4076.491

Akaike info criterion 19.76429

Sum squared resid 3.16E+08

Schwarz criterion 20.43769

Log likelihood -320.9930

Hannan-Quinn criter. 19.99394

F-statistic 74.98556

Durbin-Watson stat 2.653326

Prob(F-statistic) 0.000000

The above table $\mathrm{V}$ shows that the coefficient $\mathrm{C}_{1}$ and $\mathrm{C}_{2}$ which shows the speed of adjustment towards long run equilibrium has negative sign and is statistically significant at 5 per cent level of significance which confirms that there is long run causality from our two independent variables i.e. exports and imports. This implies that our independent variable has influence on dependent variable. The value of $\mathrm{R} 2$ is also found to be very high i.e. 0.98 and F-value is also found to be statistically significant at 5\% level of significance which shows that the overall model is significant. The individual coefficients are also found to be statistically significant which indicate the presence of shortrun causality running from exports, imports to GDP. In order to check the short-run causality running from exports to GDP and imports to GDP, we have also applied Wald test:

$\mathrm{H}_{0}: \quad \mathrm{C}(7)=\mathrm{C}(8)=\mathrm{C}(9)=\mathrm{C}(10)=0$

$\mathrm{H}_{1}: \quad \mathrm{C}(7)=\mathrm{C}(8)=\mathrm{C}(9)=\mathrm{C}(10) \neq 0$

$\mathrm{H}_{0}: \quad \mathrm{C}(11)=\mathrm{C}(12)=\mathrm{C}(13)=\mathrm{C}(14)=0$

$\mathrm{H}_{1}: \quad \mathrm{C}(11)=\mathrm{C}(12)=\mathrm{C}(13)=\mathrm{C}(14) \neq 0$

TABle Vi Short Run Causality (WALD Test)

\begin{tabular}{|c|c|c|c|}
\hline Hypothesis & Chi-Square & P-Value & $\begin{array}{c}\text { Decision At 5\% } \\
\text { Level of Significance }\end{array}$ \\
\hline $\mathrm{H}_{0}=$ GDP doesn't Granger Cause Exports & 55.57172 & 0.0000 & ${\text { Reject } \mathrm{H}_{\mathrm{o}}}^{\text {(n) }}$ \\
\hline $\mathrm{H}_{0}=$ GDP doesn't Granger Cause Imports & 32.24458 & 0.0000 & Reject $\mathrm{H}_{\mathrm{o}}$ \\
\hline
\end{tabular}

The above table VI clearly indicates that there is presence of short run causality running from exports to GDP and imports to GDP as p-value is found to be less than at 5\% level of significance in both the cases. Finally, the results of Wald test clearly indicate the presence of short run causality running from exports to GDP and imports to GDP.

\section{CONCLUSION}

The paper tries to assess empirically, tries to examine the relationship among exports, imports and economic growth (GDP) of Chinese economy using annual data over the period 1980 to 2016. Co integration test confirmed that three variables exports, imports and GDP are co integrated i.e. all the variables have long run association among them.
The Granger causality test finally confirmed the presence of bi-directional causality between exports and GDP, Imports and GDP, and exports and imports. The error correction estimates gave evidence that the Error-Correction Term is statistically significant and has a negative sign, which confirms that there isn't any problem in the long-run equilibrium relation between the independent and dependent variables. The study further reveals that there exists a significant and positive relation between exports and Gross National product (GNP) for the whole period under study i.e. 1980 to 2016. The study supports Export-Led Growth Hypothesis (ELGH) in Chinese economy over the period 1980 to 2016. Export-led growth has sustained high growth rates in China. The fast growth of the export is a result of the combination of China's double transition and it's fully 
integration into world system. Lastly, increasing share of china's exports has made a positive contribution in the Gross Domestic Product (GDP) of Chinese economy. This may be due to the aggressive economic reforms and export promotion policies adopted by the Chinese government.

\section{REFERENCES}

[1] Edwards, S. (1998). Openness, productivity, and growth: What do we really know?. Economic Journal, 108, 383-98.

[2] Esfahani, H.S. (1991). Exports, imports, and economic growth in semi-industrialized countries. Journal of Development Economics, 35, 93-116.

[3] Fan Bonai \& Zhu Hua. (2005). The Construction and Actual Investigation of Local Government Performance Evaluation. Journal of Political Science, (1): 33.

[4] Grossman Gene \& Helpman E. (1991). Innovation and Growth in the Global Economy. MIT Press, Cambridge.

[5] Gujrati Damodar (1999). Essentials of Econometrics. Published by McGraw-Hill Ltd. Company.

[6] Gujrati Damodar \& Sangeetha (2007). Basic Econometrics. Fourth Edition, New Delhi, Tata Mc. Graw Hill Publishing Company Limited.

[7] Jong Wha Lee (1995). Capital Goods Import and Long -Run Growth. NBER working paper series, Working paper No: 4725.

[8] Jordan Shan \& Fiona Sun. (1998). On The Export-led Growth Hypothesis: The Econometric Evidence from China. Applied Economics, (30).

[9] Jordan A. C. \& Eita, J. H. (2007). Export and Economic Growth in Namibia: A Granger Causality Analysis. South African Journal of Economics, 75, 3 .

[10] Kruger A. (1980). Trade Policy as an Input to Development. American Economic Review, 70, 188-292.
[11] Liu, X., Song, H. \& Romilly, P. (1997). An Empirical Investigation of the Causal Relationship between Openness and Economic Growth in China. Applied Economics, 29, 1679-1686.

[12] Lucas Robert. (1988). On the Mechanics of Economic Development. Journal of Monetary Economics, 22, 3-42.

[13] Marshall, Alfred. (1920). Principles of Economics. London.

[14] Mallick S. K. (1996). Causality between Exports and Economic Growth India: Evidence from Co-integration based Error-correction Model. Indian Journal of Economics, 76(302), 307-320.

[15] Mill, John Stuart (1848). Principles of Political Economy, 1, Published by, George Rutledge \& Sons Ltd., London.

[16] Onafowora, Olugbenga A. \& Owoye Oluwole. (1997). Trade policy, Export Performance and Economic Growth: Evidence from SubSaharan Africa. Journal of International Trade and Economic Development, 5, 341-360.

[17] Rivera-Batiz, F. L. (1985). International Finance and Open Economy Macroeconomics. New York: Macmillan.

[18] Romer Paul. (1986). Increasing returns and long Run Growth. Journal of Political Economy, 94, 1002-1037.

[19] Shan, J. \& F. Sun. (1998a). Export-led Growth Hypothesis for Australia: An Empirical Reinvestigation. Applied Economics Letters, 5, 423-428.

[20] Shan, J. \& F. Sun. (1998b). On the Export-led Growth Hypothesis: The Econometric Evidence from China. Applied Economics, 30, 1055-1065.

[21] Thangavelu, S. M., \& Rajaguru, G. (2004). Is There An Export or Import Led Productivity Growth in Rapidly Developing Asian Countries? A Multivariate VAR Analysis. Applied Economics 36(10), 1083-1094.

[22] Tang, T. C., (2006). New Evidence on Export Expansion, Economic Growth and Causality in China. Applied Economic Letters, 50, 413 416.

[23] Zhu, Z. G. (2007). A gravity model of China's trade flows, Recent Developments in the Chinese Economy. NOVA Science Publishers, Inc., 135-172. 